\title{
Kako prepoznati i stvoriti vrhunskog sportistu
}

Maja Popov
Ucitelj Transcendentalne meditacije i yoge, Švajcarska

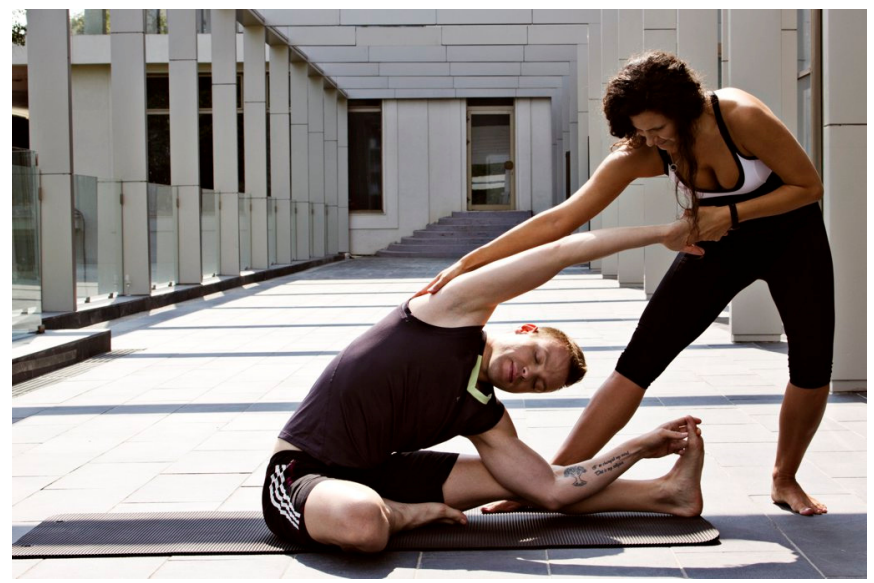




\section{Kako prepoznati i stvoriti vrhunskog sportistu}

U vreme znatnog unapređanja tehnike, taktike i fizičke pripreme u savremenom sportu svedoci smo da se došlo skoro do vrhunca ljudskih mogućnosti. Šta je ono što izdvaja vrhunske sportiste u odnosu na prosečne? Performanse vrhunskih sportista se mogu poboljšati psihološkim treningom, koučingom, podizanjem energetskih potencijala, posebnom ishranom, a sve sa ciljem unapređenja psihofizičkih funkcija organizma sportiste.

$\mathrm{Na}$ ovu temu razgovor vodimo sa Majom Popov koja je u saradnji sa vrhunskim stručnjacima razvila - Program za edukaciju trenera.

Deo njenog tima čine predavači poput $\mathrm{Dr}$ Dobrinke Arbanovski specijalista interne medicine, a u kvntanoj medicini je više od dvadeset godina, Dr Marije Aranđelović iz Centra za sportsku ishranu i suplementaciju koja takođe radi i u Antidoping agenciji Republike Srbije, Tanja Jeremić Velimirović- diplomirani psiholog, Dr Željko Mojsilović- pregovarač, kouč i trener joge sa više od dvadeset godina iskustva u treniranju specijalnih jedinica i Dr Vesna Danilović lekar, life coach.

\section{Koliki je značaj holističkog pristupa unapređenju performansi sportista?}

$\mathrm{Na}$ značaj holističkog pristupa unapređenju performansi sportista ukazuju i svetska a i domaća iskustava. U Holističkoj akademiji Maja Popov se posebna pažnja poklanja radu sa mladim sportistima koji tek treba da dostignu svoj pun potencijal, a da $u$ isto vreme sačuvaju svoje telo za dugovečno bavljenje sportom.Program edukacije trenera je osmišljen kako bi treneri, a preko njih i mladi sportisti imali više mogućnosti da čuju o holističkom pristupu vežbanju i mogućnostima koje ono pruža. U skladu sa ovim ciljevima Holistička akademija obavlja sledeće aktivnosti: razvoj i implementacija programa za poboljšanje kvaliteta života i zdravlja kroz holistički pristup, razvoj i implementacija programa iz oblasti zdravog načina života, fizičke aktivnosti i sporta, unapređenje ishrane i druge preventivne aktivnosti; razvoj i implementacija programa iz oblasti komplementarne (tradicionalne, integrativne, kvantne) medicine; razvoj ljudskih potencijala; edukacija i stručno usavršavanje $\mathrm{u}$ oblasti komplementarne medicine, psihologije, sporta i sl.
Tim za unapređenje performansi sportista je okosnica rada sa sportistima i trenerima $u$ Holističkoj akademiji.

\section{Koji su vodeći faktori za vrhunski rezultat sportiste i kako se utvrđuju?}

Vodeći faktori za vrhunski rezultat sportiste utvrđuju se na osnovu objektivnih merenja i subjektivnih procena. Objektivni način utvrđivanja vodećih faktora podrazumeva dijagnostička merenja, na osnovu kojih se dobijaju podaci o trenutnim mogućnostima sportiste, a na osnovu dobijenih rezultata može se napraviti analiza i dati smernice za dalji rad. Kod subjektivnog utvrđivanja vodećih faktora stručnjaci iz različitih oblasti (psiholog, nutricionista, kouč, i dr.), na osnovu stručnosti i iskustva daju svoju procenu vodećih faktora koji se ne mogu izmeriti. Sjedinjavanjem objektivnih i subjektivnih načina utvrđuju se vodeći faktori kod svakog igrača ponaosob, što je važno za trenažni proces i razvoj igrača.Posebno je značajan timski rad, jer brojni aspekti (takmičarski, zdravstveni, psihološki, sociološki, itd.) i kriterijumi (fizičke sposobnosti, takmičarski kvaliteti, osobine ličnosti) prevazilaze znanja, iskustva i sposobnost bilo kog stručnjaka. Sredstva i metode određuje svaki od stručnjaka na osnovu stručnosti i znanja, ali i kreativnog pristupa problematici. Utvrđivanjem bitnih faktora i korišćenjem različitih sredstava i metoda za njihovo razvijanje, sportisti se omogućava da postigne optimalno stanje organizma i razvije individualni stil koji najviše odgovara njegovim psihofizičkim mogućnostima.

\section{Koliko je zastupljena sportska psihologija na Vašoj Akademiji?}

Sportska psihologija je široka oblast koja se bavi proučavanjem psiholoških aspekata svih oblika i sadržaja fizičke kulture i ponašanja svih učesnika u njima sa ciljem da opiše, objasni, predvidi i kontroliše ta ponašanja kako bi bila usmerena $u$ pravcu postizanja lične i sportske kompetentnosti. Akteri u sportu nisu samo sportisti, već i treneri, sudije, navijači, roditelji, publika i drugi. Dijagnostifikovanjem trenutnog psihološkog statusa sportiste, trasira se put budućih, mogućih intervencija. Svaki sportista i ostali elemenati u njegovom sistemu, zahtevaju individualan pristup. Upoznavanje sa konceptom stresa i savladavanje, razvijanje veština za upravljanje istim, postaje podrška u razvoju 
samog sportiste i sistema. Radi se na preuzimanju lične odgovornosti za uspeh i neuspeh i na pronalaženju unutrašnjih izvora motivacije. Podrška sportistima, trenerima i roditeljima da iznađu način da jasno komuniciraju svoje potrebe, strahove, mesta zastoja i sl., rezultira svesnošću i omogućava optimalizaciju postignuća.

Koliki je uticaj yoge, svesnog disanja i meditacija u sportu?

Cilj koji imamo vežbajući yogu jeste uskladiti pokret, dah i pažnju.Kada dosegnemo taj uskladjeni trenutak, živimo yogu odnosno sadašnji trenutak. Učimo kako da se skoncentirsemo i da živimo sada a ne da nam misli i energija odlazi na prošlost ili budućnost koji nam u delikatnom i odlučujućem trenutku mogu biti teret.

Učimo kako da budemo fleksibilni telom, a to prebacujemo i na mentalno i emotivno stanje. Šta god da se dešava moramo biti dovoljno fleksibilni da preokrenemo situaciju u našu korist i da više verujemo u sebe. Mentalna snaga i sigurnost biće presudna kod dobijanja vrhunskih rezultata.

Zar se i disanje mora učiti?Definitivno mora.Čovek se rađa i počinje da živi tek kada udahne i napušta ovaj svet tek kada izdahne.Tako da je ključ dah, odnosno disanje. Isprekidano i plitko disanje nije dobro i pokazuje nam da se disanjem moramo redovno baviti.

Tehnika meditacije nam omogućava da zaronimo više u sebe, da se dubinski odmorimo i rehabilitujemo. Da oslobodimo duboko ukorenjeni stres i uverenja koja smo skupili kroz odrastanje a $\mathrm{u}$ nekim momentima nas blokiraju da napredujemo dalje.Cilj meditacije je razvoj viših stanja svesti, otkloniti dubinski umor i stres kako bi što budniji i što svesniji dosegli svoj pun potencijal. A svi znamo da ljudi koriste svega 5$10 \%$ od svog punog mentalnog potencijala.

\section{Kome je namenjen sportski koučing?}

Sportski koučing je mentalni koučing namenjen razvoju sportista, kako onih $\mathrm{u}$ vrhunskom profesionalnom sportu, tako i početnika. Radi se na definisanju ciljeva i mogućnosti, planiranju razvoja uspešne sportske karijere, menjanju ograničavajućih ponašanja novim, željenim i uspešnijim, razvoju potencijala i podrške. Kroz višegodišinje iskustvo rada sa vrhunskim profesionalnim sportistima napravili smo i razvijamo poseban sistem sportskog koučinga koji sadrži sledeće elemente: 1 . Rad na stresnim situacijama - blokade, negativna stanja i emocije, povrede, porazi, negativna uverenja, sukobi, 2. Aktiviranje i razvoj resursa sigurnosti, koncentracije, preciznosti, samopouzdanja, uticaja, snage, moći i pobedničkog stava, 3. Usidravanje resursnih stanja - ugrađivanje "okidača" za mogućnost trenutnog ulaska u potrebno i "željeno stanje i resurs", 4. Usavršavanje performansi usavršavanje svake performanse do "Idealne", pomeranje granica, sklanjanje limita, 5. Mentalno i emocionalno kondicioniranje - razvijanje mentalne snage, jačanje pozitivnih uverenja i emocija, 6. Vizualizovanje pobede - mentalne igre mečeva, 7. Energetsko kondicioniranje balansiranje organizma i energetskog sistema, ravnoteža čakri, energizacija tela i zaštita od negativnih uticaja.

\section{Koliki je značaj $i$ uloga ishrane $i$ suplementacija u sportu?}

Ishrana ima kompleksnu ulogu u promociji optimalnih sposobnosti sportista obezbeđujući da se organizam adekvatno snabdeva energijom i hranljivim materijama. Rezultati jednog sportiste i te kako mogu da zavise od kvaliteta, količine, kao i vremenskog unosa ishrane. Glavna uloga svakodnevne ishrane je snabdevanje sportista nutrijentima koji su potrebni za trening kao i brz oporavak između treninga.Nutritivni plan za vreme treninga i takmičenja sportista izazov je za mnoge trenere i sportske stručnjake. Razvijanje strategije u ishrani kako bi se podržala fizička sposobnost zahteva dobro poznavanje igre i potreba igrača. Definisanje mišićne mase, gubitak ili povećanje telesne težine su neki od najčešćih problema zbog kojih se vrhunski sportisti obraćaju za savet. Specifičnost ovog programa je u tome što se svakom sportu i sportisti pristupa pojedinacno a ne samo na osnovu opštih preporuka. Program sportske ishrane i suplementacije je integralni deo programa psihofizičke pripreme sportista. Veliku pomoć u ishrani imamo kroz testiranje na intoleranciju određenih namirnica, koje se kasnije izbacuju ili smanjuju u ishrani a vrlo brzo se vidi rezultat jer su igrači poletniji, bez alergija, imaju brže varenje, bolje dišu itd. Jer jako puno energije ide na hranu koju teško varimo ili smo na nju alergijčni.Čim to otklonimo dobijamo priliv zdrave i jake, pobedničke energije. 


\section{Koja funkcionalna dijagnostička sredstva primenjujete i šta obezbeđuje homeopatska terapija?}

Biorezonntna dijagnostika IMAGO sistemom i pregledom žive kapi krvi omogućava brzo otkrivanje slabih tačaka organizma i rad na uzroku problema u začetku ili onih koji bi mogli nastati. To je vrsta preventivnog pregleda pri kojem se određuje osetljivost/intolerancija na hranu, osetljivost ili prisustvo infektivnih agenasa kao što su bakterije, virusi, gljivice i paraziti, nedostatak vitamina i minerala, osetljivost pojedinih organa ili sistema organa, kao i neravnoteža energetskih protoka organizmu, a koji uzrokuju nemogućnost upotrebe (blokade ) energetskih potencijala sportiste. Sistem ima i mogućnost terapije akutnih i hroničnih tegoba, poseban program za terapiju alergija, sportskih povreda, rad na poboljšanju cirkulacije, oksigenacije i limfne drenaže. Homeopatska terapija obezbeđuje jedinstvo tretmana tela, uma i duha i preporučuje se za poboljšanje performansi svakog sportiste jer poseban akcenat daje na mentalno-emotivni sklop pojedinca i njegovo poimanje sebe, okoline i odnosa.

\section{Vi ste radili sa Novakom Đokovićem i drugim vrhunskim sportistima. Šta je to što oni najviše vole da uzmu od joge?}

Faktor koji kod njih veoma utiče na rezultat je trema, strah od pobede ili od gubitka. Vrlo često se dešava da sportisti ne pobede jer još uvek nisu spremni da daju sebi dozvolu da pobede, ne osećaju se dovoljno vrednim.Misle da moraju još mnogo da rade da bih to zaslužili. A joga ih uči da veruju u sebe da mirni ulaze u igru i iz tog mirnog stanja potpuno drugačije funkcionišu, jer odišu samopouzdanjem. Takođe im je bitno da nauče da se vrate $u$ trenutku kada ispadnu iz igre.Kada su u stanju frustracije, najvažnije je da nauče da se iz stanja povišenog adrenalina brzo vrate u normalno stanje.Kao što se fizičko stanje trenira, tako se i mentalno stanje može uvežbati. U profesionlnom sportu pobeđuje onaj koji je mentalno jači, a vrhunskim sportistima je važno da neguju svest o tome da ništa do kraja meča nije izgubljeno. Sada postoje ozbiljni timovi ljudi koji kroz vežbe, predavanja i savetovanja rade sa poznatim sportistima na mentalnom ojačavanju. Novak je toliko toga sam prošao i naučio i to nesebično deli sa ljudima i na taj način uzdiže svest kod ljudi, što je u Srbiji neophodno.

Ponekad u profesionalnom sportu osim samih sportista mora ozbiljno da se radi i sa roditeljima, jer deca brzo napreduju ali prevelika očekivanja i preveliko finansijsko breme koje roditelji imaju utiče na dete da puca i odustaje jer je to za njih prevelika odgovornost. 


\section{Biografija}

Maja Popov je rođena 1975.godine u Osijeku. Sa meditacijom i yogom se upoznala već sa 13. godina. Sa 18. godina u Ukrajini i Švajcarskoj je završila kao najmlađi učitelj Transcendentalne meditacije i yoge. Zavrsila je master studije menađmenta u sportu. Osnivač je i predsednik Holisticke Akademije Maja Popov.

Maja je sertifikovan učitelj i predstavnik za Srbiju - European Yoga Federation i Word Movemen for Yoga and Ayurveda (www.worldyogayurveda.net).

Kroz život najvišeg Vedskog znanja učila je od najvećih učitelja današnjice Maharishi Mahes Yogija (Transcendentalnu Meditaciju, Joga sutre,Ayurvedu, Djotiš, Vastu).

Kod ing.Jadranka Mikleca (www.jailankayoga.com) se i specijalizovala za Terapeutsku yogu i individualni pristup vežbanju, koji već godinama uspešno sprovodi učenicima i profesionalnim sportistima. Sistem Ashtanga yoge učila je od Davida Wiliamsa (www.ashtangayogi.com), koji je prvi upoznao zapadni svet sa Ashtanga yogom.

Idealan sistem vežbi za kičmu koje čine bazu u Terapeutskoj yogi je naučila od Maharishi Swami Dev Murtija.

Pulsnu dijagnozu i marma masažu završila je kod dr Ernesta Srota, direktora nemačke akademije za ajurvedu.

Izdala dve knjige i dva dvd-a. Dugogodišnji je saradnik mnogih časopisa, radio i TV emisija na RTS-u, B92, Pink-u, RTV-u itd. Učestvuje kao predavač na različitim seminarima.

Maja je dizajnirala svoj terapijski i individualni pristup yoge svakom pojedincu u odnosu na njegovu fiziologiju, godine ili stanje. Nije više dovoljno samo vežbati, mora se voditi mnogo računa i o ishrani, okruženju, načinu razmišljanja.Važno je da naučimo pravilno vežbati, disati i pozitivno se uzdizati. Jednom kada naučimo kako to sve primenjivati imaćemo znanje za ceo život. 